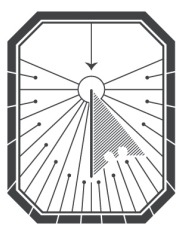

KYIV-MOHYLA

LAW \& POLITICS JOURNAL

KYIV-MOHYLA SCHOLARLY PEER-REVIEWED JOURNALS

Protection of Intellectual Property Rights in Investor-State Arbitration: Underlying Challenges and Perspectives

Author(s): Kateryna Lazarchuk, Oksana Zadniprovska

Source: Kyiv-Mohyla Law and Politics Journal 7 (2021): 77-94

Published by: National University of Kyiv-Mohyla Academy

http://kmlpj.ukma.edu.ua/ 


\title{
Protection of Intellectual Property Rights in Investor-State Arbitration: Underlying Challenges and Perspectives
}

\author{
Kateryna Lazarchuk \\ Associate \\ Hillmont Partners, Ukraine \\ Oksana Zadniprovska \\ Partner \\ Axon Partners, Ukraine
}

\begin{abstract}
This article provides an analysis of existing international mechanisms for protecting intellectual property rights and concludes whether investment arbitration can be an effective forum for resolving intellectual property disputes. It focuses on an examination of the scope of intellectual property rights protection by bilateral investment agreements, as well as the specifics of the investment dispute resolution procedure. In addition, the analysis includes an assessment of the territoriality principle of intellectual property rights and its application in Ukrainian law, as well as an examination of international investment treaties concluded with Ukraine to determine the scope of protection afforded to intellectual property.
\end{abstract}

Key Words: intellectual property rights, intellectual property disputes, IPRs holders, investment arbitration, bilateral investment treaties, foreign investment.

\section{(2)}

\section{Introduction}

Intellectual property (hereinafter - “IP”) has become a valuable intangible asset for generating profits, promoting technological innovation and stimulating an economic development. It gives the IP holders exclusive rights to use their intellectual creations for a certain period of time to prevent unauthorized use by third parties or to set conditions of such use. ${ }^{1}$ Pursuant to Article 2 of the Convention Establishing Intellectual Property Organization, the definition of "intellectual property" includes the rights relating to: (i) literary, artistic and scientific works, (ii) performances of performing

$1 \quad$ Burrone, Esteban, "Why Intellectual Property Matters: The Importance of Intellectual Property for Small and Medium-sized Enterprises," WIPO (1999), accessed October 9, 2021, https://case. edu/law/sites/case.edu.law/files/2019-10/Why\%2oIP\%2OMatters\%2O\%28WIPO\%2C\%208\%2O p.\%29.pdf. 
artists, phonograms, and broadcasts; (iii) inventions in all fields of human endeavor; (iv) scientific discoveries; (v) industrial designs; (vi) trademarks, service marks, and commercial names and designation; (vii) protection against unfair competition, and (viii) all other rights resulting from intellectual activity in the industrial, scientific, literary or artistic fields. ${ }^{2}$ As a rule, the intellectual property rights (hereinafter- "IPRs") foster innovation by increasing the potential innovation returns and allowing the IP holders to enjoy sufficient benefits from their innovation activity for justifying considerable risks. ${ }^{3}$ In practice, new technology companies are often set up with founders from different countries who invest in IP to generate profits and return them back to specific jurisdictions. This can lead to large legal disputes of a cross-border nature. Given the significant role of IP in attracting foreign direct investments and advancing technology transfers, the development of an effective international mechanism for the protection and enforcement of IPRs becomes a particularly important global task.

At present, the protection of IPRs from any infringements and the resolution of IP disputes are essentially a function of national courts. This can be explained by the territorial nature of IPRs which allows states to adopt their national IP legislation for achieving specific public goals and reaching a certain level of technological and economic development. ${ }^{4}$ Although international protection for IPRs has been available since the adoption of Paris Convention for the Protection of Industrial Property and the Berne Convention for the Protection of Literary and Artistic Works, a proliferation of international IP disputes has become a growing trend in XXI century. ${ }^{5}$ As a result of globalization processes worldwide and the gradual evolution of technology, the IP disputes are often cross-border in nature which requires flexibility in dispute resolution procedures, confidentiality of proceedings, specific knowledge and technical expertise, as well as recognition and enforcement of court decisions in different countries. This explains the recent trend towards submitting the IP disputes for international arbitration. ${ }^{6}$

2 Convention Establishing the World Intellectual Property Organization dated July 14, 1967 (amended as of September 28, 1979), accessed October 9, 2021, https://iaa-network.com/ wp-content/uploads/2021/o4/Convention-Establishing-the-World-Intellectual-PropertyOrganization.pdf.

3 Stephen Ezell, and Nigel Cory, "The Way Forward for Intellectual Property Internationally" April 25, 2019, accessed October 9, 2021, https://itif.org/publications/2019/04/25/way-forwardintellectual-property-internationally.

4 Emmanuel Kolawole Oke, "Territoriality in Intellectual Property Law: Examining the Tension between Securing Societal Goals and Treating Intellectual Property as an Investment Asset," Scripted 15, no. 2 (2018): 315, accessed October 9, 2021, https://script-ed.org/wp-content/ uploads/2018/10/oke.pdf?d=10102021.

5 Intellectual Property, Magazine of Indiana University-Purdue University Indianapolis (2007), 17, accessed October 9, 2021, https://magazine.iupui.edu/o7/o7_IUPUI_Magazine.pdf.

6 WIPO Caseload Summary (2011-2020), accessed October 10, 2021, https://www.wipo.int/amc/ en/center/caseload.html. 
Additionally, the IPRs holders can rely on the means for protecting the IPRs as a form of foreign investments under bilateral investment treaties (hereinafter - the "BITs"). In general, the BITs allow IPRs holders to benefit from the substantive and procedural protection of foreign investments, as well as from the investor-state dispute settlement mechanism (hereinafter- "ISDS") under the applicable treaty. This offers significant advantages to IP holders, as they can initiate dispute resolution proceedings against the state without exhausting all local remedies and without resorting to diplomatic protection to defend their interests. ${ }^{7}$ On the other hand, the scope of IP rights protection is different from that of any other asset that constitutes a foreign investment, which consequently raises the question of whether investment tribunals can be the appropriate forum for resolving the IP disputes.

\section{Peculiarities of the IP dispute resolution through investment treaty arbitration}

Although the IPRs are widely recognized as valuable intangible assets, their protection is significantly impaired by a specific territorial scope. This implies that the IP protection afforded by the national legislation of a certain country exists only within the territory of that country and does not extend beyond the borders. ${ }^{8}$ In particular, the territorial principle of IPRs protection is enshrined in the Ukrainian legislation. Pursuant to Article 37 of the Law of Ukraine "On Private International Law," the law of the state in which protection of IPRs is sought applies to legal relationships involving the protection of those rights. ${ }^{9}$ Specifically, under paragraph 4 of part 1 of Article 77 of this Law, the jurisdiction of Ukrainian courts is exclusive if the dispute relates to the registration of an IPR which requires the issuance of a certificate (patent) in Ukraine. Consequently, the IP holders are restricted in their choice of a suitable dispute resolution forum.

In Ukraine, the territoriality principle does not apply to IPRs that are subject to protection from the moment of their creation in a particular form (e. g.copyright), as opposed to the issuance of a protection document (patent). ${ }^{10}$ According to part 3 of Article 3 of the Law of Ukraine "On Copyright and Related Rights" copyright and

Valentina S. Vadi, "Towards a New Dialectics: Pharmaceutical Patents, Public Health and Foreign Direct Investments", Journal of Intellectual Property and Entertainment Law 5, no. 1 (2015): 3-4. Transnational Disputes (with Comments and Reporters' Notes), The American Law Institute, accessed October 10, 2021. 2-3, https://wipolex-res.wipo.int/edocs/lexdocs/laws/en/us/us218enpart14.pdf.

Zakon Ukrainy "Pro mizhnarodne pryvatne pravo" vid 23 chervnia 2005 roku [The Law of Ukraine "On Private International Law" No. 2709-IV dated June 23, 2005], accessed October 10, 2021, https://zakon.rada.gov.ua/laws/show/2709-15\#Text.

10 Viktoriia Borysenko, Zakhyst avtorskykh prav v IT, Elektronne vydannia YuRYST\&ZAKON No 35, veresen 2020 [Borysenko, Victoriia, "Protection of Copyrights in IT," Electronic Journal 
(or) related rights holders, irrespective of their citizenship, whose works or objects of related rights were first promulgated in the territory of another state, or those that were not promulgated but are located in an objective form in the territory of another state, shall be granted legal protection in accordance with the international agreements of Ukraine..1 Therefore, the national laws of Ukraine provide ample scope for foreign investors to recognize and protect copyrights due to the absence of strict territoriality rules.

It is worth noting that the international legal instruments only provide minimum standards of IP protection to which countries should adhere. For instance, Article 16:1 of the Agreement in Trade-Related Aspects of Intellectual Property Rights (hereinafterthe "TRIPS Agreement") grants the IP holders an exclusive right to prevent third parties from using "identical or similar signs for goods or services which are identical or similar to those in respect of which the trademark is registered where such use would result in a likelihood of confusion." 12 While this provision places a legal obligation on states to facilitate the exclusive right of IP holders, states are free to choose how to implement this obligation into national law and practice..$^{13}$ In addition, the TRIPS Agreement harmonizes the legislative approaches to IP protection among different countries and raises the levels of protection previously established by the Paris Convention and the Berne Convention. ${ }^{14}$ Considering that the TRIPS Agreement was adopted within the framework of the World Trade Organization (hereinafter - "WTO"), the Member States are entitled to rely on the WTO dispute settlement procedures to resolve international IP disputes.

Nowadays, a significant number of IP disputes are transboundary in nature, which involve two or more jurisdictions and can arise from a variety of sources, including cross-border licenses, technology transfer agreements, joint research and development projects, distributorship arrangements, non-disclosure agreements, branding determinations, adoption of domain names, and product design decisions. ${ }^{15}$ Resolving

“LAWYER\&LAW," No. 35, September 2020], accessed October 10, 2021, https://uz.ligazakon.ua/ ua/magazine_article/EAo14137.

11 Zakon Ukrainy "Pro avtorske pravo i sumizhni prava” № 3792-XII vid 23 hrudnia 1993 roku [The Law of Ukraine "On Copyright and Related Rights" No. 3792-XII dated December 23, 1993], accessed October 10, 2021, https://zakon.rada.gov.ua/laws/ show/3792-12\#Text. The Agreement in Trade-Related Aspects of Intellectual Property Rights, accessed October 10, 2021, https://www.wto.org/english/docs_e/legal_e/31bis_trips_O4_e.htm.

13 Article 1:1.

14 Part II Chapter 12 Protection of Intellectual Property, accessed at October 10, 2021, https://www. meti.go.jp/english/report/downloadfiles/gCTo332e.pdf.

15 Joseph P. Zammit and Jamie Hu, "Arbitrating International Intellectual Property Disputes," Mealey's International Arbitration Reports 24, no. 6, (June 2009), accessed October 10, 2021, http://arbitrationlaw.com/files/articles/aaa_arbitrating_international_intellectual_property_ disputes.pdf. 
the cross-border IP disputes in national courts can cause significant difficulties and may not lead to the necessary result due to lengthy court procedures, legislative deficiencies and a lack of special expertise of judges. Moreover, the WTO dispute settlement system also has many disadvantages, including the requirement of state representation of IP holders based on the principle of diplomatic protection..$^{16}$ Therefore, the IP holders face the problem of choosing the most effective mechanism to protect their IPRs and legitimate interests, which can be resolved by recourse to investment treaty arbitration.

The investor-state dispute settlement (hereinafter - "ISDS") is a specific procedural mechanism for resolving legal disputes between foreign investors and the states relating to breaches of the bilateral and multilateral investment treaties. ${ }^{17}$ In other words, if an investor from one country made an investment in another country, both of which have agreed to ISDS, and the host state violates its obligations under the BITs (namely, fair and equitable treatment, most-favored nation or national treatment), the investor may bring an international claim before the arbitral tribunal. ${ }^{18}$ Arbitral tribunals are composed of party-appointed arbitrators who hear the case based on the procedural rules set out in the BITs and are entrusted with interpreting the applicable investment treaties. ${ }^{19}$ Moreover, the BITs limit the jurisdiction of arbitral tribunals with respect to specific subject-matter (definition of "investment"), claimant's nationality (definition of "foreign investor") and time limits for bringing a claim into arbitration (e.g., cooling off period, statutes of limitation). ${ }^{20}$ Therefore, to initiate investment arbitration the IP holders must prove that the arbitral tribunal has jurisdiction to hear the dispute against a particular state.

The definition of foreign investment included in the BITs is crucial in determining whether arbitral tribunals have jurisdiction over the IP disputes. IPRs are fundamentally different in nature from the classic example of an investment, which should include (i) the transfer of funds, (ii) a longer-term project, (iii) the purpose of regular income, (iv)

16 Evaluation of the WTO Dispute Settlement System: Results to Date, accessed October 10, 2021, https://www.wto.org/english/tratop_e/dispu_e/disp_settlement_cbt_e/c12s3p1_e.htm.

17 Gus Van Harten and Martin Loughlin, "Investment Treaty Arbitration as a Species of Global Administrative law," The European Journal of International Law, 17, no. 1: 125-126, accessed October 10, 2021, http://www.ejil.org/pdfs/17/1/65.pdf.

18 Investor-State Dispute Settlement (ISDS), Thomson Reuters Practical Law, accessed October 10, 2021, https://uk.practicallaw.thomsonreuters.com/o-624-6147?transitionType=Default\&contex tData=(sc.Default);

19 International Investment Treaties and Investor-State Dispute Settlement, Columbis Center on Sustainable Investment, updated as of May 32, 2019, accessed October 10, 2021, https://ccsi. columbia.edu/sites/default/files/content/docs/Primer_-International-Investment-Treaties-andInvestor-State-Dispute-Settlement_o.pdf.

20 J. Pohl, K. Mashigo and A. Nohen, "Dispute Settlement Provisions in International Investment Agreements: A Large Sample Survey," OECD Working Papers on International Investment, 2012/o2 (OECD Publishing), 16, accessed October 10, 2021, https://www.oecd.org/daf/inv/ investment-policy/WP-2012_2.pdf. 
the participation of the person transferring the funds, at least to some extent, in the management of the project, and (v) a business risk. ${ }^{21}$ Furthermore, the similar criteria for determining the existence of foreign investment, which is known as the Salini test, have been developed by the arbitral tribunal's practice, namely: contribution of the investor, certain duration of the project, existence of operational risk and contribution to the host state's development.22 In turn, while being intangible assets which increase the value of income, IPRs do not satisfy all of the abovementioned criteria.

Although IPRs differ from the classical understanding of investments, the plethora of BITs concluded with Ukraine offers IPRs investment protection. In particular, according to Article 1 of the Slovenia-Ukraine BIT, the term "investment" includes, among others, intellectual property rights, including rights with respect to copyright, patents, trademarks, tradenames, industrial designs and rights in technical processes, goodwill and know-how. ${ }^{23}$ Some BITs provide a specific list of IPRs that may qualify as investments (e.g. the Belgium-Ukraine BIT), ${ }^{24}$ whereas the others cover the IPRs in general without mentioning any particular type (e. g. the Canada-Ukraine BIT). ${ }^{25}$ In addition, several BITs protect uncommon IPRs, such as sound recordings and inventions in all fields of human endeavor, ${ }^{26}$ literary and artistic works, semiconductor mask words, etc. ${ }^{27}$ The Japan - Ukraine BIT contains the most extensive list of the IPRs that constitute an investment, namely, rights relating to utility models, layout-designs

21 Rudolf Dolzer, "The Notion of Investment in Recent Practice" in S. Charnovitz, D. P. Steger and P. van den Bosche (eds.), Law in the Service of Human Dignity: Essays in Honour of Florentino Feliciano (2005), 263.

22 Rudolf Dolzer, Christoph Schreuer, "Principles of International Investment Law," 2nd Edition, Oxford Publishing, (November 2012), 68.

23 Article 1 of the Agreement between Ukraine and the Republic of Slovenia on the mutual promotion and protection of investments, effective as of June 1, 2000, accessed October 10, 2021, https://investmentpolicy.unctad.org/international-investment-agreements/treatyfiles/6250/download.

24 Article 1 of the Agreement between the Belgo-Luxemburg Economic Union and the Government of Ukraine on the Reciprocal Promotion and Protection of Investments, effective as of July 27, 2001, accessed October 10, 2021, https://investmentpolicy.unctad.org/ international-investment-agreements/treaty-files/5905/download.

Article 1 of the Agreement between the Government of Canada and the Government of Ukraine for the Promotion and Protection of Investments, effective as of July 24, 1995, accessed October 10, 2021, https://investmentpolicy.unctad.org/international-investment-agreements/ treaty-files/64o/download.

26 Article 1 of the Agreement between the Slovak Republic and Ukraine for the Promotion and Reciprocal Protection of Investments, effective as of February 20, 2009, accessed October 10, 2021, https://investmentpolicy.unctad.org/international-investment-agreements/treatyfiles/5510/download.

27 Article 1 of the Treaty between the United States of America and Ukraine Concerning the Encouragement and Reciprocal Protection of Investment, effective as of November 16, 1996, 
of integrated circuits, new varieties of plants, indications of source or geographical indications and undisclosed information. ${ }^{28}$ Conversely, the Armenia-Ukraine BIT provides the lowest level of protection to foreign IPRs, since an investor can recognize and protect only copyrights, industrial property rights, know-how and technology rights. ${ }^{29}$

Moreover, considering that most of IPRs have territorial scope, the national law plays a significant role in determining the legality of IP investments. ${ }^{30}$ For instance, Article 1 of the Finland - Ukraine BIT defines the term "investment" as every kind of asset established or acquired by an investor of one Contracting Party in the territory of the other Contracting Party in accordance with the laws and regulations of the latter Contracting Party. ${ }^{31}$ Consequently, when establishing the existence of a protected investment within the meaning of the BIT, investment tribunals should further ascertain whether the investors' IPRs are recognized by the host state, in particular, by examining whether the IPRs have been duly registered under national law.

In addition, the possible attribution of IPRs to protected investments is confirmed by the practice of investment tribunals. For instance, in the case CME Czech Republic B. V. v. the Czech Republic, the Claimant argued that it has made an investment in the Czech Republic, which includes both tangible and intangible property, in particular, buildings, studio equipment, and intellectual property rights, such as rights to air licensed programmes and the legal interest in maintaining the exclusive business arrangement between two companies. ${ }^{32}$ The arbitral tribunal accepted the Claimant's allegations on existence of foreign investment as a matter of fact and did not pay a particular attention as to whether the IPRs can qualify as protected investment.

accessed October 10, 2021, https://investmentpolicy.unctad.org/international-investmentagreements/treaty-files/2366/download.

28 Article 1 of the Agreement between Japan and Ukraine for the Promotion and Protection of Investment, effective as of November 26, 2015, accessed October 10, 2021, https:// investmentpolicy.unctad.org/international-investment-agreements/treaty-files/3324/ download.

29 Article 1 of the Agreement between the Government of Ukraine and the Government of the Republic of Armenia for the Promotion and Reciprocal Protection of Investments, effective as of March 7, 1996, accessed at October 10, 2021, https://investmentpolicy.unctad.org/ international-investment-agreements/treaty-files/6237/download. Pratyush Nath Upreti, "The Role of National and International Intellectual Property Law and Policy in Reconceptualising the Definition of Investment," IIC (2021) 52: 111-113.

31 The Agreement between the Government of the Republic of Finland and the Government of Ukraine on the Promotion and Protection of Investments, effective as of December 7, 2005, accessed October 10, 2021, https://investmentpolicy.unctad.org/international-investmentagreements/treaty-files/1220/download. 
In the recent case Bridgestone v. the Republic of Panama, the Claimants stated that they hold IPR, namely, the licenses to use trademarks in Panama which qualify as protected investment under the United States - Panama Trade Promotion Agreement. They also argued that by issuing the Supreme Court Judgment, which "undercuts one of the fundamental rights of trademarks, namely, the right to oppose the registration of potentially confusingly similar marks," the Republic of Panama denied to the American investor fair and equitable treatment. ${ }^{33}$ Even though the arbitral tribunal dismissed the claim on the merits, it has established the jurisdiction to hear the dispute arising out of trademark licenses already registered in Panama by American investor. In contrast, the arbitral tribunal in the case Cortec Mining v. the Republic of Kenya found that IPRs, including know-how, such as geological and drilling data, resource analyses, feasibility studies, technical processes and project development plans, did not qualify as protected investment since the Claimants have failed to comply with the laws of Kenya for obtaining a mining license. ${ }^{34}$ Thus, in practice, arbitral tribunals have granted only duly registered IPRs the status of a foreign investment without applying the generally recognized investment criteria.

The main advantage of resolving IP disputes through investment arbitration is the opportunity to bypass the procedural hurdles inherent in most national court systems. However, there are relatively small numbers of foreign investors resorting to IPRs protection through inter-state arbitration. Considering that IPRs have fallen under the scope of application of international investment treaties since the beginning of BITs negotiations, ${ }^{35}$ it is unclear why foreign investors do not choose this forum for protecting their intangible assets. Thus, it is important to identify existing problems of IPRs protection through investment treaty arbitration in order to establish the prospects for IP disputes to be resolved by this forum.

33 Award in the ICSID Case No. ARB/16/34, Bridgestone Licensing Services, Inc. and Bridgestone Americas, Inc. v. The Republic of Panama, August 14, 202O, para. 314, last accessed at October 10, 2021, https://www.italaw.com/sites/default/files/case-documents/italaw11771.pdf. Award in the ICSID Case No. ARB/15/29, Cortec Mining Kenya Limited, Cortec (Pty) Limited and Stirling Capital Limited v. the Republic of Kenya, October 22, 2018, paras. 313, 331, accessed October 10, 2021, https://www.italaw.com/sites/default/files/case-documents/italaw10051.pdf.

35 Lahra Liberti, "Intellectual Property Rights in International Investment Agreements: An Overview," OECD Working Papers on International Investment," 2010/01:6, accessed October 10, 2021, https://www.oecd-ilibrary.org/docserver/5kmfqinjzl35en.pdf?expires $=1634015000 \&$ id $=$ id \& accname $=$ guest $\&$ checksum $=49$ CoE97F6FF6DBo27D773A37 B325309o. 


\section{Substantive protection afforded to foreign IPRs holders by the BITs}

Foreign investors are guaranteed a certain standard of protection under the BITs which can be raised if the host state neglects foreign investments. ${ }^{36}$ As illustrated by the case law, substantive protection afforded to foreign investments include:

a) protection against expropriation or measures equivalent to expropriation without fair compensation;

b) fair and equitable treatment;

c) full protection and security;

d) protection against arbitrary and discriminatory treatment;

e) national and most-favored-nation treatment (hereinafter- "MFN");

f) free transfer of funds and assets, and

g) protection against host state's breach of its investment obligations and undertakings. ${ }^{37}$

Consequently, BITs incorporate a legal mechanism used to compensate investors through the substantive investment standards for the breach of treaty obligations by a particular state.

Although the TRIPS Agreement provides similar substantive standards (e. g., MFN and national treatment), the scope of investment protection under the BITs differs from what has been provided by the TRIPS Agreement. In particular, the WTO Panel in the EC - Trademarks and Geographical Indications clarified that "the TRIPS Agreement does not generally provide for the grant of positive rights to exploit or use certain subject matter, but rather provides for the grant of negative rights to prevent certain acts. This fundamental feature of intellectual property protection inherently grants Members a freedom to pursue legitimate public policy objectives since many measures to attain those public policy objectives lie outside the scope of intellectual property rights." 38 Consequently, the problem arises as to whether the scope of protection afforded to foreign investments under BITs is suitable for IPRs or whether it needs to be adjusted to reflect the special IP nature.

The differences in the scope of protection provided by the TRIPS Agreement and the BITs may be illustrated based on the fair and equitable treatment standard

36 Julien Chaisse, Puneeth Nagaraj, “Changing Lanes: Intellectual Property Rights, Trade and Investment," Hastings International and Comparative Law Review 37, no. 2 (2014): 247.

37 Nigel Blackaby, Constantine Partasides QC, Alan Redfern, and Martin Hunter, Redfern and Hunter on International Arbitration, (Oxford: Oxford University Press, 2015): 470.

38 Panel Report in case No. WT/DS29o/R, European Communities_Protection of Trademarks and Geographical Indications for Agricultural Products and Foodstuffs, March 15, 2005, para. 7.246, accessed October 10, 2021, https://www.worldtradelaw.net/reports/wtopanels/ectrademarkgi(panel)(australia).pdf.download. 
(hereinafter - "FET"). Under Article 41(2) of the TRIPS Agreement, "procedures concerning the enforcement of intellectual property rights shall be fair and equitable. They shall not be unnecessarily complicated or costly or entail unreasonable timelimits or unwarranted delays." 39 Thus, the TRIPS Agreement refers to the FET in relation to the IPRs enforcement procedures and does not provide it as the substantive standard for IPRs protection.

In contrast, the FET standard is an absolute standard of investment protection and is often invoked in investment treaty arbitrations. ${ }^{40}$ In theory, the FET appears to be an evolving standard that requires the host state to maintain a stable investment environment and protect legitimate expectations of foreign investors. ${ }^{41}$ The scope of FET is usually linked to the minimum standard of treatment required by customary international law. ${ }^{42}$ In the case Apotex Holdings Inc, Apotex Inc. v. the United States the Claimant contended that the import alert that banned certain pharmaceuticals produced in Canada violated MFN and the minimum standard of treatment (FET), since it has prevented the foreign investor from carrying its business activity for two years and damaged the company's interests. However, the investment tribunal dismissed the claim on the basis that the Claimants did not establish the existence of specific procedural rights required by customary international law that the challenged import alert would violate. ${ }^{43}$ Thus, in this case the foreign investor lost the case for the lack of proper justification of the FET breach by the Respondent with respect to the Claimant's intangible assets.

In practice, foreign investors frequently allege the expropriation of their IPRs by the host state without any compensation. A change of the political course or an economic crisis may result in host states trying to gain economic advantages by expropriating foreign investments. ${ }^{44}$ BITs usually refer to direct and indirect expropriation or measures equivalent or tantamount to expropriation. ${ }^{45}$ Direct expropriation means

39 The Agreement in Trade-Related Aspects of Intellectual Property Rights, accessed October 10, 2021, https://www.wto.org/english/docs_e/legal_e/27-trips_05_e.htm. Bertran Boie, "The Protection of Intellectual Property Rights through Bilateral Investment Treaties: Is there a TRIPS-plus Dimension?” Working Paper, No. 2010/19, November 2010, 16. Ian Meredith, "Investment treaties: Taking advantage of the protections on offer," CrossBorder Quarterly, July-September 2006, 29, accessed October 11, 2021, https://files. klgates.com/files/publication/e38do478-ba59-48c6-9cee-3a6cc7752bae/presentation/ publicationattachment/3d33ea17-3a8a-4893-a438-3e510a156o91/inv_treat.pdf. OECD, "Fair and Equitable Treatment Standard in International Investment Law," OECD Working Papers on International Investment, 2004/O3, OECD Publishing, 8, accessed October 11, 2021, https://www.oecd.org/daf/inv/investment-policy/WP-2004_3.pdf.

Award in ICSID Case No. ARB(AF)/12/1, Apotex Holdings Inc, Apotex Inc. v. the United States, August 25, 2014 paras. 2.27-2.28, 9.40, accessed October 11, 2021, https://www.italaw.com/sites/ default/files/case-documents/italaw3324.pdf. 
a mandatory legal transfer of the title to the property or its outright physical seizure, whereas an indirect expropriation involves the deprivation of an investment without formal transfer to title or outright seizure. ${ }^{46}$ As illustrated by an arbitral practice, an expropriation must involve a substantial deprivation of the value, use or enjoyment of an investment and not merely a loss of profits. ${ }^{47}$

For instance, in case Philip Morris and Abal Hermanos S. A. v. Uruguay, the Claimants argued that the Respondent expropriated their investment by banning most of their brand variants and diminishing the value of the remaining ones. Claimants contended that they have been foreign investors within the meaning of the BIT since they possess a direct or indirect interest in the "brand assets" that they have developed in Uruguay, namely, the brands, brand families and variants of cigarettes, as well as the trademarks associated with the brand markings on the products and a goodwill. In turn, the Respondent claimed that adoption of restrictions on marketing tobacco products did not result in expropriation since it has exercised its sovereign power to protect public health. The arbitral tribunal dismissed the claim on expropriation of foreign investment on the basis that the BIT "does not prevent Uruguay in the exercise of its sovereign powers from regulating harmful products in order to protect public health after investments in the field have been admitted." 48 Hence, the arbitral tribunal decided that the Respondent did not expropriated the Claimants' investments since it validly exercised its police powers for the protection of public health. ${ }^{49}$

In another case Eli Lilly and Company v. Canada the Claimant stated that the retroactive application of the promise utility doctrine by national courts to Claimant's patents has resulted in the unlawful indirect expropriation of foreign investment and the Respondent's failure to provide the minimum standard of treatment. In turn, the Respondent argued that a foreign investor "cannot circumvent an adverse determination of its rights at domestic law simply by pointing to an alleged inconsistency with some other, independent international obligation owed between States." ${ }^{50}$ The arbitral tribunal supported the Respondent's arguments and emphasized that the tribunal cannot review the decisions of the national judiciary. Moreover, the tribunal found

46 Expropriation, UNCTAD Series on Issues in International Investment Agreements II, United Nations (2012), 6-7, accessed October 11, 2021, https://unctad.org/system/files/officialdocument/unctaddiaeia2o11d7_en.pdf.

Expropriation (including of intellectual property/trademarks), "WHO Framework Convention on Tobacco Control," accessed October 11, 2021, https://untobaccocontrol.org/kh/legal-challenges/ investment/expropriation/. Award in the ICSID Case No. ARB/10/7, Philip Morris Brands SARL, Phillip Morris Products S. A. and Abal Hermanos S. A. v. Oriental Republic of Uruguay, July 8, 2016, para. 288, accessed October 11, 2021, https://www.italaw.com/sites/default/files/case-documents/italaw7417.pdf. Para. 307 . Final Award in case No. UNCT/14/2, Eli Lilly and Company v. the Government of Canada, March 16, 2017, para. 191, accessed October 11, 2021, https://www.italaw.com/sites/default/files/ case-documents/italaw8546.pdf. 
that the challenged decision cannot constitute a breach of investment treaty, since the Canadian legal system has evolved and resulted in later decisions that found the initial patent grants to be invalid. Consequently, the tribunal rejected the claim due to the Claimant's failure to establish the factual premise of its claims. ${ }^{51}$ Therefore, in order to prove the expropriation of IPRs by the host state, the foreign investor must provide sufficient evidence that the state has substantially diminished the value of its IPRs and that such actions were not necessary to achieve a specific public goal.

In addition, some BITs include special exceptions regarding application of expropriation standard to IPRs. Under Article 13.5 of the Canadian Model BIT, "the provision of this Article [Expropriation] shall not apply to the issuance of compulsory licenses granted in relation to intellectual property rights, or to the revocation, limitation or creation of intellectual property rights, to the extent that such issuance, revocation, limitation or creation is consistent with the WTO Agreement." 52 In other words, this provision prevents foreign investors from invoking a violation of the expropriation standard by the issuance or revocation of compulsory licenses. Hence, when analyzing the prospects of filing an investment dispute against a state, the foreign investor should consider whether the text of the BIT contains any reservations related to the IPRs treatment.

To summarize, the practice of arbitral tribunals confirms that the scope of protection afforded to IPRs under investment treaties is insufficient to make the ISDS an effective forum for resolving IP disputes. This can be explained by the fact that national laws and domestic policies play an important role in determining violations of investment protection standards, such as the FET and the expropriation standard. As a result, a foreign investor has relatively less opportunity to justify a breach of BIT.

\section{Conclusion}

Although arbitral tribunals have confirmed that IPRs can be protected investments, the substantive standards of investment protection provided in the BITs are not suitable for the effective IPRs protection. The case law shows that foreign investors encounter difficulties in proving a violation of BITs, in particular, since (i) the states usually invoke a special public policy goal to justify their actions (e. g., the tobacco plain packaging regulations), (ii) some BITs specifically contain the reservations that prevent application of substantive standards to IPRs protection, (iii) it is necessary to prove the registration of IPRs in the territory of the host state against which the dispute is filed, and (iv) substantive standards of investment protection are not flexible in relation to IPRs. Accordingly, unless the substantive standards provided in the BITs are modified to accommodate the specific nature of IP protection, the investment arbitration will not

\footnotetext{
$51 \quad$ Paras. 225 and 418.

$5^{2}$ Expropriation, UNCTAD Series on International Investment Agreements II, United Nations (2012), 16, accessed October 11, 2021, https://unctad.org/system/files/official-document/ unctaddiaeia2o11d7_en.pdf.
} 
be the best forum for resolving the IP disputes. Thus, this issue should also be included in the ISDS reform agenda.

\section{Bibliography}

Agreement between Ukraine and the Republic of Slovenia on the mutual promotion and protection of investments, effective as of June 1, 2000. Accessed October 10, 2021. https://investmentpolicy.unctad.org/international-investment-agreements/ treaty-files/625o/download.

Agreement between the Belgo-Luxemburg Economic Union and the Government of Ukraine on the Reciprocal Promotion and Protection of Investments, effective as of July 27, 2001. Accessed October 10, 2021. https://investmentpolicy.unctad.org/ international-investment-agreements/treaty-files/5905/download.

Agreement between the Government of Canada and the Government of Ukraine for the Promotion and Protection of Investments, effective as of July 24, 1995. Accessed at October 10, 2021. https://investmentpolicy.unctad.org/international-investmentagreements/treaty-files/64o/download.

Agreement between the Slovak Republic and Ukraine for the Promotion and Reciprocal Protection of Investments, effective as of February 20, 2009. Accessed October 10, 2021. https://investmentpolicy.unctad.org/international-investment-agreements/ treaty-files/5510/download.

Agreement between Japan and Ukraine for the Promotion and Protection of Investment, effective as of November 26, 2015. Accessed at October 10, 2021. https://investmentpolicy.unctad.org/international-investment-agreements/ treaty-files/3324/download.

Agreement between the Government of Ukraine and the Government of the Republic of Armenia for the Promotion and Reciprocal Protection of Investments, effective as of March 7, 1996, Accessed October 10, 2021. https://investmentpolicy.unctad. org/international-investment-agreements/treaty-files/6237/download.

The Agreement between the Government of the Republic of Finland and the Government of Ukraine on the Promotion and Protection of Investments, effective as of December 7, 2005, Accessed October 10, 2021. https://investmentpolicy. unctad.org/international-investment-agreements/treaty-files/1220/download.

Agreement in Trade-Related Aspects of Intellectual Property Rights. Accessed October 10, 2021. https://www.wto.org/english/docs_e/legal_e/31bis_trips_04_e.htm.

Award in the ICSID Case No. ARB/16/34, Bridgestone Licensing Services, Inc. and Bridgestone Americas, Inc. v. The Republic of Panama, August 14, 2020, para. 314. Accessed October 10, 2021. https://www.italaw.com/sites/default/files/casedocuments/italaw11771.pdf.

Award in the ICSID Case No. ARB/15/29, Cortec Mining Kenya Limited, Cortec (Pty) Limited and Stirling Capital Limited v. the Republic of Kenya, October 22, 2018, 
paras. 313, 331. Accessed October 10, 2021. https://www.italaw.com/sites/default/ files/case-documents/italawıoo51.pdf.

Award in ICSID Case No. ARB(AF)/12/1, Apotex Holdings Inc, Apotex Inc. v. the United States, August 25, 2014 paras. 2.27-2.28, 9.4O. Accessed October 11, 2021. https:// www.italaw.com/sites/default/files/case-documents/italaw3324.pdf.

Award in the ICSID Case No. ARB/10/7, Philip Morris Brands SARL, Phillip Morris Products S. A. and Abal Hermanos S. A. v. Oriental Republic of Uruguay, July 8, 2016, para. 288. Accessed October 11, 2021. https://www.italaw.com/sites/default/ files/case-documents/italaw7417.pdf.

Blackaby, Nigel, and Constantine Partasides QC, Alan Redfern, Martin Hunter. Redfern and Hunter on International Arbitration. Oxford: Oxford University Press, 2015.

Boie, Bertram. "The Protection of Intellectual Property Rights through Bilateral Investment Treaties: Is there a TRIPS-plus Dimension?" Working Paper No. 2010/19 (November 2010).

Borysenko, Viktoriia. "Zakhyst avtorskykh prav v IT [Protection of Copyrights in IT]." Electronic Journal "LAWYER\&LAW" 35 (September 2020). Accessed October 10, 2021. https://uz.ligazakon.ua/ua/magazine_article/EAo14137.

Burrone, Esteban. "Why Intellectual Property Matters: The Importance of Intellectual Property for Small and Medium-sized Enterprises.” WIPO (1999) Accessed October 9, 2021. https://case.edu/law/sites/case.edu.law/files/2019-10/Why\%2OIP\%2O Matters\%20\%28WIPO\%2C\%208\%2op.\%29.pdf.

Chaisse, Julien, Puneeth Nagaraj. "Changing Lanes: Intellectual Property Rights, Trade and Investment." Hastings International and Comparative Law Review 37, no. 2 (2014).

Convention Establishing the World Intellectual Property Organization dated July 4, 1967 (amended as of September 28, 1979). Accessed October 9, 2021. https://iaanetwork.com/wp-content/uploads/2021/o4/Convention-Establishing-the-WorldIntellectual-Property-Organization.pdf.

Dolzer, Rudolf, Christoph Schreuer, "Principles of International Investment Law" 2nd Edition, Oxford: Oxford Publishing, 2012.

Expropriation, UNCTAD Series on Issues in International Investment Agreements II, United Nations (2012). 6-7. Accessed October 11, 2021. https://unctad.org/system/ files/official-document/unctaddiaeia2o11d7_en.pdf.

Expropriation (Including of Intellectual Property/trademarks). "WHO Framework Convention on Tobacco Control.” Accessed October11, 2021. https://untobaccocontrol. org/kh/legal-challenges/investment/expropriation/.

Evaluation of the WTO Dispute Settlement System: Results to Date. Accessed October 10, 2021, https://www.wto.org/english/tratop_e/dispu_e/disp_settlement_cbt_e/ c12s3p1_e.htm.

Ezell, Stephen and Nigel Cory. "The Way Forward for Intellectual Property Internationally" dated April 25, 2019. Accessed October 9, 2021. https://itif.org/ publications/2019/04/25/way-forward-intellectual-property-internationally. 
Rights in Investor-State Arbitration: Underlying Challenges and Perspectives

Final Award in case No. UNCT/14/2, Eli Lilly and Company v. the Government of Canada, March 16, 2017, para.191. Accessed October 11, 2021. https://www.italaw.com/sites/ default/files/case-documents/italaw8546.pdf.

Van Harten, Gus and Martin Loughlin. "Investment Treaty Arbitration as a Species of Global Administrative Law." The European Journal of International Law 17, no. 1. Accessed October 10, 2021. http://www.ejil.org/pdfs/17/1/65.pdf.

Intellectual Property, Magazine of Indiana University-Purdue University Indianapolis (2007), 17. Accessed October 9, 2021, https://magazine.iupui.edu/o7/o7_IUPUI_ Magazine.pdf.

Intellectual Property: Principles Governing Jurisdiction, Choice of Law and Judgements in Transnational Disputes (with Comments and Reporters' Notes), The American Law Institute. Accessed October 10, 2021. https://wipolex-res.wipo.int/edocs/ lexdocs/laws/en/us/us218en-part14.pdf.

Investor-State Dispute Settlement (ISDS). Thomson Reuters Practical Law. Accessed October 10, 2021. https://uk.practicallaw.thomsonreuters.com/o-624-6147?trans itionType=Default\&contextData $=($ sc.Default $)$.

International Investment Treaties and Investor-State Dispute Settlement, Columbis Center on Sustainable Investment, updated as of May 32, 2019. Accessed October 10, 2021, https://ccsi.columbia.edu/sites/default/files/content/docs/Primer_International-Investment-Treaties-and-Investor-State-Dispute-Settlement_o.pdf.

Kolawole Oke, Emmanuel, "Territoriality in Intellectual Property Law: Examining the Tension between Securing Societal Goals and Treating Intellectual Property as an Investment Asset." Scripted. 15, no.2 (2018), Accessed October 9, 2021. https:// script-ed.org/wp-content/uploads/2018/10/oke.pdf?d=10102021.

Liberti, Lahra, "Intellectual Property Rights in International Investment Agreements: An Overview." OECD Working Papers on International Investment." 2010/o1:6. Accessed October10, 2021. https://www.oecd-library.org/docserver/5kmfqinjzl35en. pdf ?expires $=1634015000 \&$ id $=i d \&$ accname $=$ guest $\&$ checksum $=49$ CoE97F6 FF6DBo27D773A37B325309o.

Meredith, Ian. "Investment Treaties: Taking Advantage of the Protections on Offer." Cross-Border Quarterly. (July-September 2006) Accessed October 11, 2021. https:// files.klgates.com/files/publication/e38do478-ba59-48c6-9cee-3a6cc7752bae/ presentation/publicationattachment/3d33ea17-3a8a-4893-a438-3е510a156o91/ inv_treat.pdf.

OECD. "Fair and Equitable Treatment Standard in International Investment Law." OECD Working Papers on International Investment, 2004/o3, OECD Publishing, 8, Accessed October 11, 2021. https://www.oecd.org/daf/inv/investment-policy/ WP-2004_3.pdf.

Part II Chapter 12 Protection of Intellectual Property. Accessed October 10, 2021. https:// www.meti.go.jp/english/report/downloadfiles/gCTo332e.pdf.

Pohl, J., K. Mashigo and A. Nohen. "Dispute Settlement Provisions in International Investment Agreements: A Large Sample Survey." OECD Working Papers on 
International Investment, 2012/o2 (OECD Publishing). 16 Accessed October 10, 2021. https://www.oecd.org/daf/inv/investment-policy/WP-2012_2.pdf.

Pratyush Nath Upreti. "The Role of National and International Intellectual Property Law and Policy in Reconceptualising the Definition of Investment." IIC (2021) 52: $111-113$.

Partial award in case CME Czech Republic B. V. (The Netherlands) v. the Czech Republic, the UNCITRAL Arbitration Proceedings, September 13, 2001, para. 147, Accessed October 10, 2021. https://www.italaw.com/sites/default/files/case-documents/ itao178.pdf.

Panel Report in case No. WT/DS29o/R, European Communities - Protection of Trademarks and Geographical Indications for Agricultural Products and Foodstuffs, March 15, 2005, para. 7.246, Accessed at October 10, 2021. https:// www.worldtradelaw.net/reports/wtopanels/ec-trademarkgi(panel)(australia). pdf.download.

Rudolf Dolzer, "The Notion of Investment in Recent Practice" in S. Charnovitz, D. P. Steger and P. van den Bosche (eds.), Law in the Service of Human Dignity: Essays in Honour of Florentino Feliciano (2005).

Treaty between the United States of America and Ukraine Concerning the Encouragement and Reciprocal Protection of Investment, effective as of November 16, 1996, Accessed October 10, 2021. https://investmentpolicy.unctad. org/international-investment-agreements/treaty-files/2366/download.

Vadi, Valentina S. "Towards a New Dialectics: Pharmaceutical Patents, Public Health and Foreign Direct Investments", Journal of Intellectual Property and Entertainment Law 5, no. 1 (2015).

WIPO Caseload Summary (2011-2020). Accessed October 10, 2021. https://www.wipo. int/amc/en/center/caseload.html.

Zakon Ukrainy "Pro mizhnarodne pryvatne pravo" No 2709-IV vid 23 chervnia 2005 roku [The Law of Ukraine "On Private International Law" No. 2709-IV dated June 23, 2005]. Accessed October 10, 2021. https://zakon.rada.gov.ua/laws/show/270915 \#Text.

Zakon Ukrainy "Pro avtorske pravo i sumizhni prava" No 3792-XII vid 23 hrudnia 1993 roku [The Law of Ukraine "On Copyright and Related Rights" No. 3792-XII dated December 23, 1993]. Accessed October 10, 2021, https://zakon.rada.gov.ua/laws/ show/3792-12\#Text.

Zammit, Joseph P. and Jamie Hu, "Arbitrating International Intellectual Property Disputes." Mealey's International Arbitration Reports 24, no. 6, (June 2009), Accessed October 10, 2021, http://arbitrationlaw.com/files/articles/aaa_ arbitrating_international_intellectual_property_disputes.pdf

\section{iv}

Kateryna Lazarchuk is an Associate with the International Dispute Resolution Practice at Hillmont Partners. She specializes on complex domestic litigation, cross-border 
Rights in Investor-State Arbitration: Underlying Challenges and Perspectives

dispute resolution and international arbitration. She has advised on disputes arising from contract law issues and non-contractual liability, bankruptcy and debt collection, as well as on exports and imports of goods and services.

Oksana Zadniprovska is an Attorney-at-law and a Partner at Axon Partners. She advises the IT companies on privacy, including data protection and compliance, intellectual property and contract law. She has acted as a counsel to technocrats, the IT business of any size and categories (start-ups and incubators, outsourcing companies, product companies, etc.). 


\title{
Захист Прав Інтелектуальної Власності у Інвестиційному Арбітражі: Основні Виклики та Перспективи
}

\author{
Катерина Лазарчук \\ Юрист \\ Hillmont Partners, Україна

\section{Оксана Задніпровська} \\ Партнер \\ Axon Partners, Україна
}

\begin{abstract}
Анотація
У статті здійснено аналіз чинних міжнародних механізмів захисту прав інтелектуальної власності та робиться висновок про те чи може інвестиційний арбітраж ефективним майданчиком для вирішення спорів 3 питань інтелектуальної власності. Особлива увага звертається на дослідження обсягу прав інтелектуальної власності у двосторонніх інвестиційних договорах, а також на процедурні особливості розгляду інвестиційних спорів. У статті також аналізується принцип територіальності прав інтелектуальної власності та його застосування в українському праві, а також досліджуються міжнародні інвестиційні договори, стороною яких є Україна, з метою визначення рівня захисту інтелектуальної власності.
\end{abstract}

Ключові слова: права інтелектуальної власності, спори з питань інтелектуальної власності, правовласники об'єктів інтелектуальної власності, інвестиційний арбітраж, двосторонні інвестиційні угоди, іноземне інвестування 